\title{
Capital Structure Determinants of S\&P BSE 500: A Panel Data Research
}

\author{
Shalini R, Mahua Biswas
}

\begin{abstract}
The paper identifies the most important factors specific to companies which impacts on the capital structure of 416 companies belonging to 14 industrial sectors listed in $S \& P$ BSE 500 for a duration of 19 years which is from 2000 to 2018. Multi regression model is used to understand the influence of select variables on capital structure. The study finds that 4 explanatory variables like firm size, tax paid, depreciation to total assets ratio and profitability ratio are statistically significant capital structure determinants.

Index Terms: Capital structure, financial leverage, firm size, tax paid, profitability

JEL classification: G32
\end{abstract}

\section{INTRODUCTION}

Capital structure is a combination of various securities known as debt equity ratio in a corporate firm. The decision regarding the composition of debt and equity are considered to be one of the most crucial decisions of a company as it has a direct bearing on the success or failure of the company. A number of theories have been proposed and lot of research has been done in the past five decades on the capital structure decisions and the factors which influence them. This topic gained special importance due to subsequent publication of seminal papers by Modigliani and Miller (1959, 1961). It has been more than five decades that neither the research nor the theory has been able offer acceptable answer as to which factors influence the capital structure decisions (Brealey and Myers 1991).

Extensive research has been conducted on developed markets whereas emerging economies is still deficient of such meticulous investigation. There have been quite a few noteworthy papers conducted on country-to-country comparisons (Jong\& Kabir 2008, Rajan and Zingales, 1995). Researchers like Bhaduri (2002), Harvey et al (2004) etc have focused on a few European and Asian countries. Bhaduri has conducted research specific to India with highly noteworthy results but chose a few number of variables and small sample due to limitation of data. Due to the uniqueness of India as a country, it becomes important to understand the behaviour of the firms by studying the nation individually.

There is also some degree of work done specific to India related to capital structure theories and determinants (Booth (2001), Bhaduri (2002); Singh and Kumar (2008); Farhat et al (2009). India as an emerging economy is based on

Revised Manuscript Received on July 5, 2019.

Shalini R, Management Dept, Bangalore University / Adarsh Institute of Management and Information Technology, Bangalore, India,

Dr. Mahua Biswas, Department of Management Studies, Bangalore University/ Dayananda Sagar College of Arts, Science and Commerce, Bangalore, India. common law with comfortable external debt environment. It has the potential for enormous expansion and the economy has been growing significantly in recent years. So, it becomes important for us to understand the significance of capital structure decisions at the micro and macro level of financing. (Joy Pathak) So it becomes extremely important for finance policy-makers at the firm or comprehensive level to understand what drives corporate financing. S\&P BSE 500 companies are considered to be the most liquid stocks. This index nearly covers $93 \%$ of the total market capitalization of Bombay Stock Exchange. It considers all the major industrial sectors of the country. Hence this study is taken up to find out the factors that determine the capital structure of all BSE 500 companies excluding financial companies.

\section{LITERATURE REVIEW}

Lot of research has been done in the area of the determinants of capital structure in several countries across the world.

\section{A.International evidences}

Rajan \& Zingales (1995) find growth, tangibility, profitability and size as the important variables in their study. Similar results have been witnessed in Sheluntkova (2014) where size, protifability, asset structure and liquidity influence the capital structure. Alzomaia (2014) shows the relationship which is positive between profitability, size, and leverage. Joshua Abor (2008) indicates that size, earnings, age, risk, tangibility and managerial ownership are significant in impacting the capital structure of Ghanian firms. Cortex \& Susanto (2012) reveal that profitability, and tangibility ratio are statistically impactful. Frank \& Goyal (2007) shows that the most reliable factors are tangibility, profits, $\log$ of assets, market to book ratio and expected inflation.

\section{B.Indian evidences}

Pathak (1997) studies six determinants influencing the leverage of select firm. Baral (2004) indicates that rate of growth, size and rate of earnings are significant variables of capital structure of companies which listed in the exchange. Shalini \& Biswas (2017) finds that factors specific to oil companies which influence the capital structure are liquidity, size of investment, fixed assets assets to total assets ratio and earnings. Rasoolpur (2014) shows interesting result wherein ratio of selling expenses to sales and current ratio are the important factors determining of capital structure. Shalini \& Biswas (2019), studies the capital structure of FMCG companies using panel data analysis, it is found that growth opportunity, business risk are earnings are significant. Riyazahmed (2012) finds that

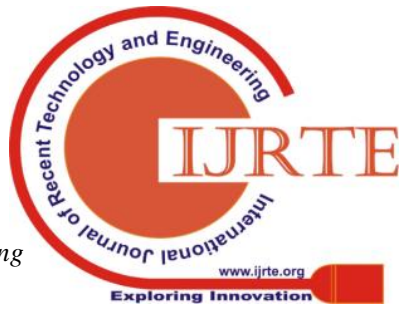


capacity serve the debt, dividend payout, degree of operating leverage, and business risk is statistically significant factors determining the financial leverage. Pandey (2000) shows that earnings, business risk, firm size, growth rate, and tangibility ratio have noteworthy impact on different types of debt. Shalini \& Biswas (2016) shows that current ratio is positively correlated with the capital structure of power sector companies in our country. Kakani \& Reddy (1998) shows that profitability, capital intensity and earnings volatility are negatively impacting the capital structure of the firm.

\section{C.Financial Leverage as a dependent variable}

Leverage has been defined in various ways. (Rajan \& Zingales, 1995), focused on defining the leverage based on the objective of the study. Leverage may be defined as debt to net assets or debt to firm value or debt to capitalization or debt to total assets etc. Debt to capital or debt to total assets is regularly used leverage in most of the empirical studies. Some of the previous research studies done by Chung, 1993, Pandey et.al, 2000, Titman \& Wessels 1988, use different types of measures of leverage. Riyazahmed (2012) has used financial leverage as a measured variable in his study.

\section{D.Other Empirical evidences}

Sinha \& Bansal (2013), Pandey (2000), Sheluntkova (2014), Joshua Abor (2008), Rasoolpur (2012), Baral (2004) have used multi regression analysis to analyse the dependent and independent variable. Picu et.al. (1999) have done a conceptual study considering the cyclical factors affecting the capital structure. Frank \& Goyal (2007) have used sign test to analyse the factors determining the capital structure. Alzomia (2014) has used cross sectional pooled data methodology for analyzing the capital structure determinants. Song (2005) has used fixed effect panel data model of regression due to availability of large amount of data over a period of time. Omet et.al (2015) have used unrelated regression analysis and panel data for their study. Cortez et.al have used multi regression and panel data to analyse the relationship of various factors.

The studies related to capital structure analysis in India have so far concentrated only on small number of sample companies with a focus on a limited number of variables. Hence the present study attempts to evaluate the determinants of capital structure of companies listed in S\&P BSE 500 .

\section{METHODOLOGY}

\section{A.Source of Information}

Secondary data is used in this study. The data is sourced from CMIE Prowess. Various National and International journals and the companies' annual reports were also used to collect the relevant data.

\section{B.Period of the study}

Data is collected fora period of 19 years i.e., 2000-2018.

\section{C.Sampling \& Population}

To achieve the objective of this research, the companies which are included are S\&P BSE 500 as on Nov 2018. Of the total 500 companies, banking and financial companies have been excluded from this study due to unusual signs (Pandey2000). Again, due to the missing data, some companies have been removed from the list. Sector wise total number of companies selected for this study is as follows:

Table 1: List of Sectors and Companies

\begin{tabular}{|l|l|}
\hline Sector & No. of Companies \\
\hline Automobile & $\mathbf{2 4}$ \\
\hline Chemicals & $\mathbf{3 9}$ \\
\hline Consumer durables & $\mathbf{1 2}$ \\
\hline Construction & $\mathbf{3 5}$ \\
\hline Communication & $\mathbf{2 6}$ \\
\hline Diversified & 11 \\
\hline Energy & 29 \\
\hline Engineering & $\mathbf{3 6}$ \\
\hline FMCG & $\mathbf{5 0}$ \\
\hline Health care & $\mathbf{4 3}$ \\
\hline Metals & $\mathbf{2 1}$ \\
\hline Services & $\mathbf{5 1}$ \\
\hline Technology & $\mathbf{2 5}$ \\
\hline Textiles & 14 \\
\hline Total & $\mathbf{4 1 6}$ \\
\hline
\end{tabular}

\section{D.Statement of Hypothesis}

The hypothesis tested for the present study is to examine the relationship between independent variables and the capital structure of select BSE 500 companies.

$\mathrm{H}_{0}$ : There is no significant influence of independent variables on the financial leverage of select BSE 500 companies.

\section{E.Specification of the model}

Since the data is time series and cross sectional in nature, panel data analysis is done. STATA 13 has been used for this purpose. Pooled OLS regression and Hausman test (to check fixed effect and random effect) is done. To test the assumptions of the regression, autocorrelation, heteroscedasticity and stationarity is conducted. The capital structure of any company is measured in terms of its leverage ratios. Here, the capital structure of the select firms is measured in terms of Total Debt to Total assets Ratio.

The three estimation models, pooled OLS, the fixed effects, and the random effects is given below:

LEVit $=\beta 0+\beta 1$ SIZEit $+\beta 2$ TAXit $+\beta 3 U N Q t+$ $\beta 4 N D T S i t+\beta 5$ TANGit $+\beta 6$ PROFit $+\beta 7$ GROWit + $\beta 8 B R I S K i t+\varepsilon i t$

\section{Where:}

LEVit= total debt to assets ratio

GROWit= percentage change in total assets

TANGit $=$ fixed assets to total assets ratio

NDTSit= depreciation to total assets ratio.

SIZEit $=\log$ of total sales

PROFit= EBIT to total assets ratio.

UNQit $=$ selling costs to sales 
TAX PAID $i t=$ tax provision to PBT ratio

BRISKit=variance in operating profit

$\beta 0=$ intercept.

$B 1-\beta 8=$ Coefficients

cit $=$ error term

Analysis of Regression results - Pooled OLS regression

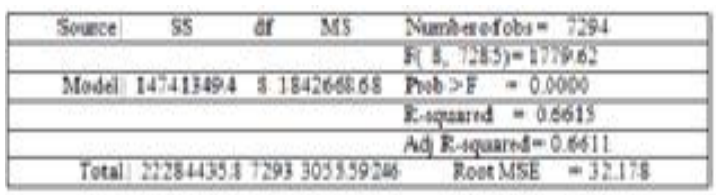

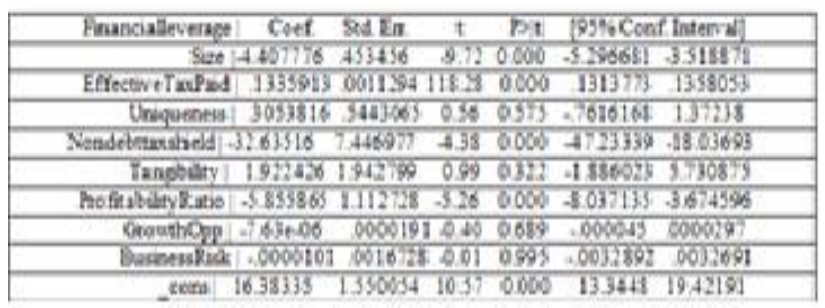

From the above table it can be seen that the $\mathrm{p}$ value is significant at $5 \%$ for variables like size, tax paid, non-debt tax shield and profitability ratio. $\mathrm{R}$ square is 0.6615 .

The findings of the study are in congruence with some of the earlier research like Rasoolpur (2012), Kavitha (2014), Amraoui et al (2018).

\section{Fixed effect model}

\begin{tabular}{|c|c|}
\hline Fixed-effects (w)ha) it: & Stots Numbet ofobs = \\
\hline Group vanable Year & Nindoer of groups $=19$ \\
\hline R-18: within $=0.0612$ & Oosper greup min = 324 \\
\hline beticen $=0.7384$ & $\arg =$ \\
\hline overd: $=0.6615$ & $\max =$ \\
\hline & $=1773.08$ \\
\hline $\operatorname{cocer}(0,1, X b)=-0.0058$ & $=0.0000$ \\
\hline
\end{tabular}

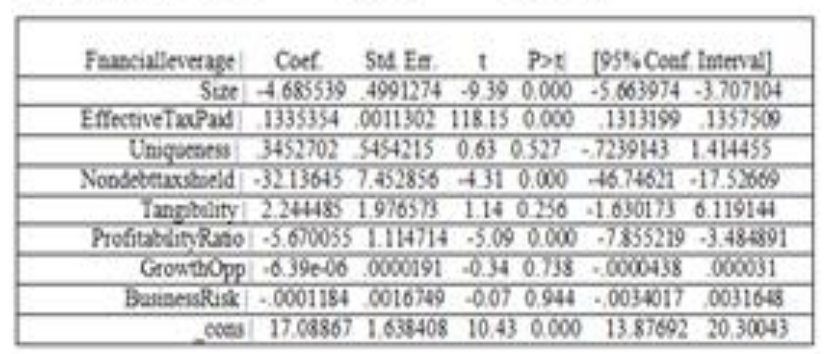

Cross sectional fixed effect model with LSDV (Least Square Dummy Variable) is represented in the above table. It can be observed that variables like size, tax paid, depreciation to total assets (NDTS) and earnings ratio are statistically significant at $5 \%$ level of significance. R square is 0.6612

\section{Random Effect model}

\begin{tabular}{|ccc|}
\hline Random-effects GLS regression & Number of obs $=7294$ \\
\hline Group variable: Year & Number of groups $=19$ \\
\hline R-sq: within $=0.6612$ & Obs per group: $\min =$ & 324 \\
\hline between $=0.7428$ & avg $=383.9$ \\
\hline overall $=0.6615$ & max $=419$ \\
\hline & Wald chi2 $(8) \quad=14233.17$ \\
\hline corr $\left(\mathrm{u}_{\text {_i }}, \mathrm{X}\right)=0$ (assumed) & Prob $>$ chi2 $=0.0000$ \\
\hline
\end{tabular}

\begin{tabular}{|r|cccccc|}
\hline Financialleverage & Coef. & Std. Err. & $\mathrm{z}$ & $\mathrm{P}>\mid \mathrm{z}$ & {$[95 \%$ Conf. Interval] } \\
\hline Size & -4.472736 & .4637379 & -9.64 & 0.000 & -5.381645 & -3.563826 \\
\hline EffectiveTaxPaid & .1335772 & .0011292 & 118.29 & 0.000 & .1313639 & .1357905 \\
\hline Uniqueness & .3172311 & .5444127 & 0.58 & 0.560 & -.7497983 & 1.38426 \\
\hline Nondebttaxshield & -32.48761 & 7.446169 & -4.36 & 0.000 & -47.08183 & -17.89338 \\
\hline Tangibility & 1.992132 & 1.949529 & 1.02 & 0.307 & -1.828873 & 5.813138 \\
\hline ProfitabilityRatio & -5.805748 & 1.112903 & -5.22 & 0.000 & -7.986998 & -3.624497 \\
\hline GrowthOpp & $-7.29 \mathrm{e}-06$ & .0000191 & -0.38 & 0.702 & -.0000447 & .0000301 \\
\hline BusinessRisk & -.00004 & .0016728 & -0.02 & 0.981 & -.0033187 & .0032386 \\
\hline cons & 16.54098 & 1.583452 & 10.45 & 0.000 & 13.43747 & 19.64449 \\
\hline
\end{tabular}

Cross sectional Random effect GLS model is represented in the above table. It can be seen that variables like size, effective tax paid, NDTS and profitability are statistically significant at $5 \%$ level of significance. R square is 0.6612

\section{Hausman Test}

While working with Panel data, the researcher has to choose between fixed effect or random effect model. These techniques help to control time invariant inter-firm heterogeneity. Hausman test is used to choose the suitable model and in cases where the level of significance of the chi-square test is lower than 5\%, then fixed effects model has to be applied. Hence this test has been conducted to find out whether fixed effect model is appropriate or random effect model is appropriate for this study.

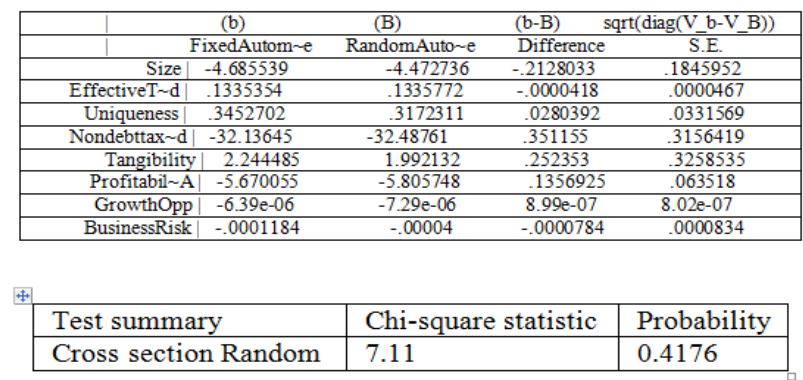

$\mathrm{H}_{0}$ : Random effect is appropriate

Since $\mathrm{P}>0.05$, Null hypothesis is accepted, that means for this study, random effect is appropriate and Fixed effect model is not appropriate.

Preconditions of Regression like stationarity, heteroscedasticity and autocorrelation are tested.

Test of Stationarity

Dickeey-Fuller test for stationarity No. of obs $=7293$

\begin{tabular}{|ccccc|}
\hline & Test & $1 \%$ Critical & $5 \%$ Critical & $10 \%$ Critical \\
\hline & Statistic & Value & Value & Value \\
\hline $\mathrm{Z}(\mathrm{t})$ & -85.480 & -3.960 & -3.410 & -3.120 \\
\hline
\end{tabular}

The approx. $\mathrm{p}$-value for $\mathrm{Z}(\mathrm{t})=0.0000$

Since Absolute value of Test Statistic is > all other 3 values, Null Hypothesis should be rejected. It means that the data is stationary.

Breusch-Pagan /

Cook-Weisberg test for 


\section{heteroskedasticity}

\begin{tabular}{|l|}
\hline Ho: Constant variance \\
\hline Variables: fitted values of Financialleverage \\
\hline chi2 $(1)=179.56$ \\
\hline Prob $>$ chi2 $=0.0000$ \\
\hline
\end{tabular}

Since $\mathrm{p}$ is not greater than 0.05 , heteroscedasticity

assumption is not met.

\section{Test of Autocorrelation}

Durbin-Watson d-statistic 2.003992

A Durbin-Watson value of 2 indicates that there is no auto-correlation in the sample data set.

\section{ConClusion}

Out of the 8 explained variables, only four variables, size, effective tax paid, depreciation to total assets ratio and profitability are statistically very important determinants of financial leverage. Hence the companies under study should focus on these variables which deciding their capital structure. This study can be further extended by doing sectoral analysis. This analysis will specifically identify the factors which influence capital structure of companies belonging to each industrial sector. Such analysis will help the companies to design an optimum capital structure and increase their profits and reduce risks. Finally, due to the limitation in gathering secondary data, the research has a limitation in collecting data only for 19 years. And again, only firm specific factors are considered for this study. The paper would like to expand the research for a longer and bigger panel data in near future along with macro-economic factors. Nevertheless, this study is a first step undertaken for research project to examine capital structure of BSE 500 companies.

\section{REFERENCES:}

1. Abe de Jong, Rezaul Kabir, Thuy Thu Nguyen, Capital structure around the world: The roles of firm- and country-specific determinants, Journal of Banking \& finance, vol.32, No.9, 2007.

2. Brealey, R.A., \& Myers, S.C, Principles of Corporate Finance. McGraw-Hill, New York,1991

3. Graham J. and Harvey C. 'How do the CFO's make Capital Budgeting and the Capital Structure Decisions? The Journal of Applied Corporate Finance, Volume 15, No 1, p 8-23, 2002

4. Joshua Abor, Determinants of the Capital Structure of Ghanaian Firms, AERC Research Paper 176, AERC, Nairobi, ISBN 9966-778-23-3, 2008

5. Joy Pathak, What Determines the Capital Structure of Listed Firms in India? Some Empirical Evidences from Indian Capital Market, http://ssrn.com/abstract=1561145.

6. Kavitha R, Determinants of Capital Structure: Empirical Evidence from India, IJAR, Volume : 4, Issue : 7, ISSN - 2249-555X, 2014

7. Keshar J. Baral, Determinants of Capital Structure: A Case Study of the Listed Companies of Nepal, The Journal of Nepalese Business Studies Vol. I No. 1,2004

8. Laurence Booth, VaroujAivazian, AsliDemirguc -Kunt\& Vojislav Maksimovic, Capital structure in the Developing Countries, The Journal of Finance, Vol LVI, No. 1,2001

9. Michael Angelo Cortez, Stevie Susanto, Determinants of corporate capital structure: Evidence from Japanese manufacturing companies, Journal of International Business Research, Volume 11, Special Issue, Number 3, 2012

10. Miller, Merton and Modigliani, Franco The Cost of Capital, Corporation Finance, and the theory of Investment, American Economic Review, $48: 261-297.15, .1958$

11. Miller, M. H. and Modigliani, F. Dividend Policy, Growth and the Valuation of Shares, Journal of Business, 34, pp 411-33, 1961

12. Mouna Amraoui, Ye Jianmu, Kenza Bouarara, Firm's Capital Structure Determinants and Financing Choice by Industry in Morocco,
International Journal of Management Science and Business Administration, vol. 4, issue 3, pp. 41-51, 2018

13. Murray Z. Frank and Vidhan K. Goyal Capital Structure Decisions: Which Factors are Reliably Important?, Financial Management, 38-1, 1-37, 2007

14. Pandey IM, Capital structure and Market Power Interaction: Evidence from Malaysia, Capital Market Review, Vol. 10, No.1, pp.23-40, 2002

15. Ram kumarkakani and V N Reddy, Econometric analysis of the capital structure determinants, IIM, Calcutta, working paper series. WPS No.333, 1998

16. Raghuram G. Rajan \& Luigi Zingales, What do we know about capital structure? Some evidence from International data, The Journal of Finance, Vol. L, No. 5, 1995

17. Rasoolpur Gurnam Singh, An empirical analysis of capital structure determinants: Evidence from the Indian Corporate sector, International Journal of Management and Information Technology, vol.1, No. 3, 2012

18. Riyazahmed K, Determinants of Capital structure: A case study of automobile manufacturing companies listed in NSE, International Journal of Marketing, Financial service and marketing research, Vol.1, No. 4,2012

19. Sheltunkova Maria, Capital structure of private pharmaceutical companies in Russia, International Journal of Economic and Management, 8 (2): 315 - 325, 2014

20. Sheridan Titman \& Roberto Wessels, The Determinants of Capital Structure Choice, The Journal of Finance, Vol.XLIII, No.1, 1988

21. Sinha Pankaj \& Bansal VishakaOnline at http://mpra.ub.uni-muenchen.de/49878, 2013

22. Singh, Priyanka and Kumar Brajesh Singh, Priyanka and Kumar, Brajesh, Trade Off Theory or Pecking Order Theory: What Explains the Behavior of the Indian Firms 2008

23. Soumitra N Bhaduri, Determinants of Capital structure choice: A study of the Indian corporate sector, Journal of Applied Financial economics, Volume12, issue 9, 2002

24. Turki SF Alzomaia,, Capital structure determinants of publicly listed companies in Saudi Arabia, The International journal of Business and Finance Research, Vol.8, No.2, 2014.

25. Shalini R, Dr. Mahua Biswas, Empirical study on the capital structure decisions of select pharmaceutical companies in India, IOSR-JBM, e-ISSN: 2278-487X, p-ISSN: 2319-7668. Volume 19, Issue 5. Ver. II (May. 2017), PP 26-30

26. Shalini R, Dr. Mahua Biswas, Impact of Capital Structure Decisions on the Operating Performance of Select Companies in Power Sector of India - A Correlation Analysis, IJEMR, vol.6, issue 3, 2016

27. Shalini R, Dr. Mahua Biswas, Capital structure determinants of FMCG companies listed in S\&P BSE 500: A Panel data analysis, published in International Journal of Research and Analytical Reviews, special issue, Feb 2019

\section{AUTHORS PROFILE}

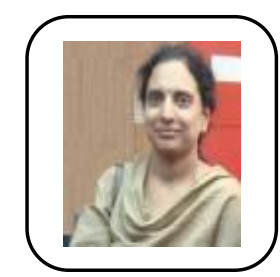

Shalini R is currently working as Associate Professor in Adarsh Institute of Management and Information Technology. She is currently pursuing her $\mathrm{PhD}$ in Management from Bharathiar University. The current area of Research is in the field of Capital Structure and its determinants. She has done her MBA, MPhil, PGDFM and is NET qualified. She has presented papers in various National and International Conferences including at IIM-B, IIM-K, IIT-M and IISc. She has published papers in Scopus and UGC indexed journals. She is the recipient of multiple Best Paper Awards.

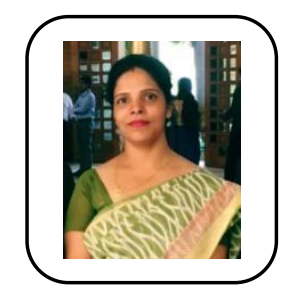

Dr. Mahua Biswas is currently associated with Department of Management Studies (BU), Dayananda Sagar College of Arts, Science and Commerce as an Assistant professor. She has earned her Ph.D from Assam University (A Central University) in the year 2010. She has done MBA (Fin), M.Com, B.Com (Hons. Accy) and DISM. She is a Certified SAP (FI) consultant. Dr. Biswas is a registered $\mathrm{PhD}$ supervisor of many universities and guiding $\mathrm{PhD}$ scholar for many years. Her areas of research include behavioral finance, corporate finance, forensic accounting, sustainability reporting, credit risk management to name a few. She also has several publications to her credit in various Scopus indexed peer reviewed UGC approved journals and contributed many papers at national and international conferences and recipient of many Best Paper Awards. She has been invited as a resource person in different institutions

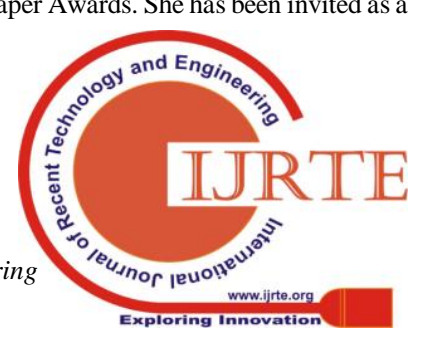

